\title{
Internet Literacy among College Students: An Empirical Research on Characteristics of College Students' Internet literacy
}

\author{
Wenying Wu, Wangxin Jing \\ Dalian University of Technology, China
}

Correspondence Author: Wenying Wu, Dalian University of Technology, China

Received date: 12 May 2019, Accepted date: 24 September 2019, Online date: 5 October 2019

Copyright: (c) 2019 Wenying Wu, et al. This is an open-access article distributed under the terms of the Creative Commons Attribution License, which permits unrestricted use, distribution, and reproduction in any medium, provided the original author and source are credited.

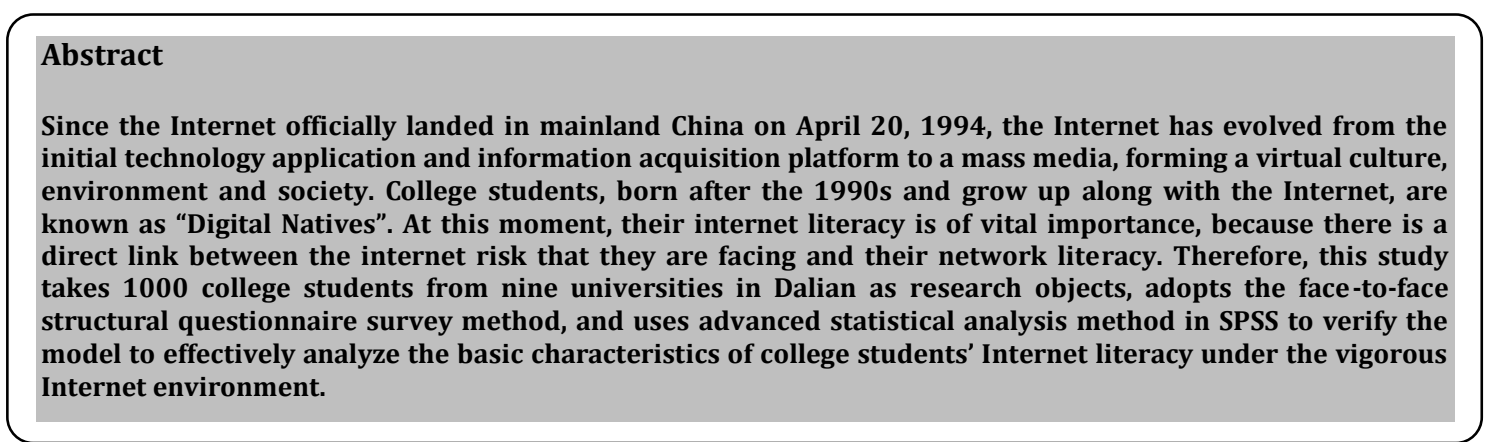

Keywords: Internet literacy; Characteristics; College students

\section{INTRODUCTION}

The Internet was officially born in 1992, and its rapid development has brought tremendous changes to the lives and behaviors of people in all parts of the world. Nowadays, the number of Chinese Internet users is the highest in the world, and the popularizing rate has exceeded the world average. The influence of the Internet on personal lifestyles has also been further deepened, from personalized applications based on communication, entertainment needs and information acquisition to people's livelihood services that are deeply integrated with public services such as education, transportation, and medical care.

College students, having the right foreign language conditions, are curious about new things, and have a strong desire for knowledge. They can use their ample time and the university's available software and hardware environment to surf the Internet and enjoy the online world. According to the 38th Statistical Report on Internet Development in China, by June 2016, the proportion of netizens aged 20-29 in China was 30.4\%, accounting for the highest percentage of netizens. Besides, college students are an essential part of the netizen group, and their ability to use and adapt to the new Internet technology is much stronger than other netizens. Therefore, the Internet literacy of college students directly affects the healthy development of the Internet environment.

At present, mainland scholars have carried out researches on college students' network literacy, but there are few empirical studies on the characteristics of college students' network literacy. Therefore, this paper uses empirical data as support to explore the actual features of college students' network literacy. The result can be used as a reference to conduct Internet literacy education to help college students resist the negative impact of the Internet.

\section{Literature Review}

2.1 Definition and connotation of Internet literacy

With the rapid progress of the Internet, Internet literacy has become an essential part of media literacy. Nowadays in many societies, people realize that it's necessary for schools to start courses on media literacy to improve students' critical media awareness and capabilities resisting unsafe information.

The course has four components: "(1) locate, evaluate, synthesize and use data from a variability of foundations; (2) understand and use basic research techniques appropriate to the course discipline; (3) recognize the several conducts in which information is organized and structured; and (4) understand the ethical subjects involved in accessing and using information".

Similarly, Shapiro and Hughes proposed and operationalized Internet literacy as a seven-dimensional construct: (1) Tool literacy refers to the ability to understand and use practical and conceptual information technology tools in respective professional life; (2) Resource literacy means the ability to understand the form, place, access procedures, and setups of information resources; (3) Social-structural literacy reveals the understanding of how information is socially situated and produced; (4) Research literacy indicates the ability to recognize and use appropriate data technology tools for research; (5) Dissemination literacy reflects the ability to format and publish research and ideas in textual and multimedia formats; (6) Emergent technology literacy refers to the awareness and the capability to adapt to, recognize, evaluate, and make use of emerging information technology; and (7) Critical literacy reveals the ability to critically evaluate the strengthens and weaknesses, capabilities and limits, of information technologies.

Jiang Hongda believes Internet literacy means using Internet data rationally to help one's living and expansion on the basis of learning Internet knowledge, and it consists of six parts: (1) Internet media cognition literacy. (2) Internet media recognition literacy. (3) Internet morality and legislation literacy. (4) Internet safety literacy. (5) Internet behavior self-management literacy. (6) Internet innovation literacy.

2.2 Research on Internet literacy from multiple perspectives 
Citation: Wenying Wu, et al., 2019. Internet Literacy among College Students: an Empirical Research on Characteristics of College Students' Internet literacy. Journal of Applied Sciences Research., 15(3): 7-12. DOI: 10.22587/jasr.2019.15.5.2

Scholars often put the Internet literacy of netizens with information search capabilities, online self-learning, academic writing, distance education, online contact behavior, and internet addiction together to carry out researches. For example, scholar Tayie, Pathak-Shelat et al. used Egypt, Finland, Kenya and other countries as examples to analyze how young people use media tools to search for information in the era that traditional and emerging search channels are coexisting.

In addition, Chinese scholars are more inclined to investigate the network literacy of different groups. Most of them are focusing on students groups, such as children, or middle school students. College students are the most common research objects.

Based on the above, two research questions are raised:

$\mathrm{RQ}_{1}$ : how do external factors, such as family income, living place, their father's highest academic degree influence the characteristics of Internet literacy of college students?

$\mathrm{RQ}_{2}$ : how do internal factors of college students, such as their gender, their majors, their uses of the Internet and their view on Internet influence the characteristics of Internet literacy of college students?

\subsection{Research on Internet literacy education}

With the growing status of online media, the Internet literacy of netizens has become an important part of modern media literacy and modern media literacy education. In the past ten years, network literacy education has attracted extensive attention from academic and educational circles in various countries. Foreign scholars have done a lot of research on the content, connotation, goals and educational methods of network literacy education, and have achieved many practical results with research value.

Popular culture has a natural appeal to young people. Falter pointed out that the youth group is the main body of campus popular culture. At the same time, from the perspective of social culture, Parry pointed out that young people are keen on popular culture, mainly because they can participate in the mass media and share experiences with others, suggesting that schools should carry out media literacy education, and education should incorporate popular cultural elements and give correct guidance to deepen young people's understanding of society and culture.

However, the vulgarization of mass media content, ethics and media hegemony often lead to the thinking of educators. Burnett and MerChant believe that in the process of dealing with the complex and changing social media phenomenon, the application framework of critical media literacy in traditional critical education has limitations, thus proposes a conceptual model reflecting the relationship between practice, identity and network, aiming at teenagers, and help them change from "what to do" to "what should be done" when using social media.

In the area of home Internet literacy education, Nikken and Jansz conducted an online questionnaire survey of 792 parents in the Netherlands, focusing on parental intervention and guidance behaviors for children. The study found that parents use strategies, which are similar to those of TV and video games, when guiding children to use the Internet. These strategies include "common use", "active mediation" and "restrictive mediation"; In addition, parents use a new strategy: "Supervision" and "Technical Safety Guidance." Based on this topic, one research question is raised:

$\mathrm{RQ}_{3}$ : How does family Internet literacy education influence the characteristics of Internet literacy of college students?

\section{Methods}

\subsection{Sample and Sampling Procedure}

This study was conducted in Dalian, a coastal city in Northeastern China. There are nine main universities or colleges in the city, including Dalian University of Technology, Dalian Maritime University, Dongbei University of Finance and Economics, Liaoning Normal University, Dalian Medical University, Dalian University of Foreign Language, Dalian Polytechnic University, City Institute of Dalian University of Technology, and Dalian Neusoft University of Information. Considering the overall population and sex ratio of these universities, the authors used random sampling and quota sampling methods. The interviews were conducted in student dormitories at the nine universities.

Of the 1000 respondents, 200 were from Dalian University of Technology, 100 were Dalian Maritime University, 100 were from Dongbei University of Finance and Economics, 200 were from Liaoning Normal University, 100 were from Dalian Medical University, 50 were from Dalian University of Foreign Language, and 100 were from Dalian Polytechnic University. The sample consisted of $47.4 \%$ males and 52.6\% females. Among them, 26.4\% were Year One students, 26.2\% were Year Two, 24.8\% were Year Three, and 22.6\% were Year Four. In total, 962 valid questionnaires are collected, the response rate is $96.2 \%$.

Data were gathered based on a probability sample of these nine universities, by using a face-to-face, structured questionnaire interview done by research assistants from November 10th 2015 to November 24th 2015.

\subsection{Measures}

The statistical software of SPSS17.0 was used in this study. Specifically, descriptive statistics, factor analysis, variance analysis, multiple regression analysis and other methods were conducted for data analysis. The reliability tests were conducted, and the reliability for the scales was remarkably high at .75 and above.

\section{Data analysis and findings}

\subsection{Factor analysis of college students' Internet literacy}

The scale used to measure Internet literacy was firstly proposed by Shapiro and Hughes and then be translated and localized by some Chinese scholars, which is using a 4-point Likert scale. In this study, all the variables to be measured were included in the factor analysis. However, due to a large number of variables in this study, according to Beniler and Chou, the variables can be divided into several groups and then conduct the Factor analysis. The four-level scale is used in the questionnaire, " $1=$ very disagree", " $2=$ disagree", " $3=$ agree", " $4=$ strongly agree", the higher the scores, the higher the Internet literacy. Except for the $9^{\text {th }}$ and $16^{\text {th }}$ question, which is the reverse question, the higher the scores, the lower the Internet literacy.

Table 1: KMO and Bartlett's Test Results of Internet Literacy Scale

\begin{tabular}{|c|c|c|}
\hline \multicolumn{2}{|c|}{ Kaiser-Meyer-Olkin } & 0.876 \\
\hline \multirow{3}{*}{ Bartlett } & Approximate X & 4834.663 \\
\cline { 2 - 3 } & df & 231 \\
\cline { 2 - 3 } & Sig. & .000 \\
\hline
\end{tabular}

By factor analysis of 24 primary variables, the KMO value was 0.876 , indicating that the data of this group is suitable for factor analysis. Then using principal component analysis to analyze the factors, five main elements of college students' Internet literacy are extracted, which can accumulate 50.078\% of the total variance. At the same time, each item is unloaded on the correct factor and the load is above 0.4 , indicating that the scale is structurally sufficient.

According to the results of factor analysis in this part, the five main factors (or five dimensions) constitute the diagnostic performance of Internet literacy.

The first dimension is the security and moral literacy, which is the ability to handle bad information on the network, protect its security, and comply with the network morality and civilization. The second dimension is emerging technology literacy, which is the ability to understand and use software technologies, network tools, and the ability to query, evaluate, and use information resources. The third dimension is the innovative literacy, which is the ability to use the network to communicate well with others, and the ability to use the network media to broaden horizons, develop ourselves, and use innovative networks. The fourth dimension is web publishing literacy, which is the ability to cautiously post personal or other information on the web and use relevant technical tools for research. The fifth dimension is the self-discipline and critical literacy, which is the self-management capabilities for the use of the network and the ability to critically respond to network information; 
Citation: Wenying Wu, et al., 2019. Internet Literacy among College Students: an Empirical Research on Characteristics of College Students' Internet literacy. Journal of Applied Sciences Research., 15(3): 7-12. DOI: 10.22587/jasr.2019.15.5.2

(1) The network literacy of science and engineering college students is higher than that of liberal arts college students

Table 2: Internet literacy of different major college students



Note: $\mathrm{SE}=$ science and engineering, $\mathrm{LA}=$ liberal arts, $\mathrm{EM}=$ economy and management, $\mathrm{M}=$ medical, $\mathrm{A}=$ art, $*$ indicate $\mathrm{p}<0.05, * *$ indicate $\mathrm{p}<0.01, * * *$ indicate $\mathrm{p}<0.001$, \# indicate $\mathrm{p}<0.10$

It can be seen from Table 2 that there are significant differences in the Internet literacy total scores $\quad(\mathrm{F}=2.940, \mathrm{p}<0.05)$, emerging technology literacy ( $\mathrm{F}=4.198, \mathrm{p}<0.01)$, innovative literacy $(\mathrm{F}=4.160, \mathrm{p}<0.01)$ and self-discipline and critical literacy $(\mathrm{F}=2.201, \mathrm{p}<0.10)$ among college students of different professional categories.

Table 3: ANOVA of different major college students' Internet literacy

\begin{tabular}{|c|c|c|c|c|c|}
\hline & & SS & df & $\mathrm{F}$ & LSD \\
\hline \multirow{3}{*}{$\begin{array}{c}\text { Internet literacy } \\
\text { Total score }\end{array}$} & Groups & 955.057 & 5 & \multirow{3}{*}{$2.940^{*}$} & \multirow{3}{*}{$\begin{array}{c}\text { Science and Engineering }>\text { liberal arts; } \\
\text { science and engineering }>\text { medical } \\
\text { Economic Management }>\text { Arts; } \\
\text { Economics }>\text { Medical }\end{array}$} \\
\hline & $\begin{array}{l}\text { Within- } \\
\text { group }\end{array}$ & 62103.491 & 956 & & \\
\hline & Total & 63058.567 & 961 & & \\
\hline \multirow{3}{*}{$\begin{array}{l}\text { Emerging technology } \\
\text { literacy }\end{array}$} & groups & 118.012 & 5 & \multirow{3}{*}{$4.198 * *$} & \multirow{3}{*}{$\begin{array}{c}\text { Science and Engineering }>\text { liberal arts; } \\
\text { science and engineering }>\text { medicine } \\
\text { Art }>\text { Arts; Art }>\text { Medical } \\
\text { Art }>\text { Other; Economics }>\text { Medical }\end{array}$} \\
\hline & $\begin{array}{l}\text { Within- } \\
\text { group }\end{array}$ & 5374.883 & 956 & & \\
\hline & Total & 5492.895 & 961 & & \\
\hline \multirow[b]{3}{*}{ Innovative literacy } & Groups & 91.441 & 5 & \multirow[b]{3}{*}{$4.160 * *$} & \multirow{3}{*}{$\begin{array}{c}\text { Science and Engineering }>\text { liberal arts; } \\
\text { Science and Engineering }>\text { Medical } \\
\text { Science and Engineering }>\text { Other; } \\
\text { Arts }>\text { Medical } \\
\text { Art }>\text { Medical; Management }>\text { Arts } \\
\text { Economic Management }>\text { Medical; } \\
\text { Management }>\text { Other }\end{array}$} \\
\hline & $\begin{array}{l}\text { Within- } \\
\text { group }\end{array}$ & 4203.262 & 956 & & \\
\hline & Total & 4294.703 & 961 & & \\
\hline \multirow{3}{*}{$\begin{array}{l}\text { self-discipline and } \\
\text { critical literacy }\end{array}$} & Groups & 24.452 & 5 & \multirow{3}{*}{$2.201 \#$} & \multirow{3}{*}{ Science and Engineering $>$ Arts } \\
\hline & $\begin{array}{l}\text { Within- } \\
\text { group }\end{array}$ & 2124.126 & 956 & & \\
\hline & Total & 2148.578 & 961 & & \\
\hline
\end{tabular}

Note: $*$ indicate $\mathrm{p}<0.05, * *$ indicate $\mathrm{p}<0.01, * * *$ indicate $\mathrm{p}<0.001, \#$ indicate $\mathrm{p}<0.10$

As can be seen from Table 3, in terms of "network literacy overall": the science and engineering group is significantly higher than the liberal arts group and the medical group; the economy and management group is significantly higher than the liberal group and the medical group.

As far as the "emerging technology literacy" dimension is concerned, the science and engineering group is significantly higher than the liberal arts group and the medical group; the art group is significantly higher than the liberal, medical and other groups; the management group is significantly higher than the medical group.

As far as "innovative literacy" is concerned, the science and engineering group is significantly higher than the liberal arts group, the medical group and other groups; the art group is significantly higher than the medical group; the management group is significantly higher than the liberal arts group, medical group and other group groups.

As far as "self-discipline and critical literacy" is concerned, the science and engineering group is significantly higher than the liberal arts group.

(3) There are differences in the Internet literacy level of college students with different family incomes

Table 4: The condition of college students' Internet literacy of different household incomes

\begin{tabular}{|c|c|c|c|c|c|c|c|c|}
\hline & \multicolumn{5}{|c|}{ Household Income } & \multirow{2}{*}{$\mathrm{F}$} & \multirow{2}{*}{$\mathrm{P}$} \\
\hline & & 1 & 2 & 3 & 4 & 5 & & \\
\hline \multirow{3}{*}{$\begin{array}{l}\text { Internet literacy total } \\
\text { score }\end{array}$} & $\mathrm{N}$ & 60 & 270 & 334 & 228 & 70 & \multirow{3}{*}{$4.464 * *$} & \multirow{3}{*}{0.001} \\
\hline & $\mathrm{M}$ & 70.01 & 71.69 & 73.00 & 73.66 & 74.41 & & \\
\hline & SD & 8.42 & 7.68 & 8.01 & 8.12 & 8.97 & & \\
\hline \multirow{2}{*}{$\begin{array}{l}\text { Security and moral } \\
\text { literacy }\end{array}$} & $\mathrm{M}$ & 19.03 & 19.12 & 19.34 & 19.28 & 19.19 & \multirow{2}{*}{0.323} & \multirow{2}{*}{0.862} \\
\hline & SD & 3.08 & 2.87 & 2.87 & 2.80 & 3.00 & & \\
\hline \multirow{2}{*}{$\begin{array}{c}\text { Emerging } \\
\text { technology literacy }\end{array}$} & $\mathrm{M}$ & 14.03 & 14.50 & 15.31 & 15.34 & 15.80 & \multirow{2}{*}{$10.234 * * *$} & \multirow{2}{*}{0.000} \\
\hline & $\mathrm{SD}$ & 2.39 & 2.35 & 2.19 & 2.39 & 2.81 & & \\
\hline
\end{tabular}


Citation: Wenying Wu, et al., 2019. Internet Literacy among College Students: an Empirical Research on Characteristics of College Students' Internet literacy. Journal of Applied Sciences Research., 15(3): 7-12. DOI: 10.22587/jasr.2019.15.5.2

\begin{tabular}{|c|c|c|c|c|c|c|c|c|}
\hline \multirow{2}{*}{ Innovative literacy } & $\mathrm{M}$ & 10.37 & 10.63 & 10.80 & 11.05 & 11.53 & \multirow{2}{*}{$3.932 * *$} & \multirow{2}{*}{0.004} \\
\hline & SD & 2.08 & 2.06 & 2.14 & 2.07 & 2.16 & & \\
\hline \multirow{2}{*}{ Publishing literacy } & $\mathrm{M}$ & 9.58 & 9.86 & 9.79 & 9.98 & 9.66 & \multirow{2}{*}{1.155} & \multirow{2}{*}{0.329} \\
\hline & SD & 1.49 & 1.49 & 1.59 & 1.61 & 1.89 & & \\
\hline \multirow{2}{*}{$\begin{array}{l}\text { Self-discipline and } \\
\text { critical literacy }\end{array}$} & $\mathrm{M}$ & 8.23 & 8.70 & 8.65 & 8.78 & 9.09 & \multirow{2}{*}{$2.903^{*}$} & \multirow{2}{*}{0.021} \\
\hline & SD & 1.51 & 1.45 & 1.49 & 1.53 & 1.49 & & \\
\hline
\end{tabular}

Note : * indicates $\mathrm{p}<0.05, * *$ indicates $\mathrm{p}<0.01, * * *$ indicates $\mathrm{p}<0.001$; family income column: " 1 " stands for " 1000 yuan or less (month)", "2" stands for " 1001 3000 yuan", " 3 " stands for "3001-5000 yuan", "4" stands for "5001-10000 yuan", and "5" stands for "10001 yuan or more".

As we can see from table 4, in terms of Internet literacy total score $(\mathrm{F}=4.464, \mathrm{p}<0.01)$ and emerging technology literacy $(\mathrm{F}=10.234$, $\mathrm{p}<0.001)$, innovative literacy $(\mathrm{F}=3.932, \mathrm{p}<0.01)$ and self-discipline and critical literacy $(\mathrm{F}=2.903, \mathrm{p}<0.05)$, there are significant differences existing between college students with different household incomes.

Table 5: ANOVA of college students' Internet literacy of different household incomes

\begin{tabular}{|c|c|c|c|c|c|}
\hline & & SS & df & $\mathrm{F}$ & LSD \\
\hline \multirow{3}{*}{ Internet literacy total score } & Groups & 1155.041 & 4 & \multirow{3}{*}{$4.464 * *$} & \multirow{3}{*}{$\begin{array}{c}5>1 ; 5>2 ; 4>1 ; 4>2 \\
3>1 ; 3>2 ;\end{array}$} \\
\hline & Within-group & 61903.526 & 957 & & \\
\hline & total & 63058.567 & 961 & & \\
\hline \multirow{3}{*}{ Emerging technology literacy } & Groups & 225.329 & 4 & \multirow{3}{*}{$10.234 * * *$} & \multirow{3}{*}{$\begin{array}{c}5>1 ; 5>2 ; 4>1 ; 4>2 \\
3>1 ; 3>2 ;\end{array}$} \\
\hline & Within-group & 5267.566 & 957 & & \\
\hline & Total & 5492.895 & 961 & & \\
\hline \multirow{3}{*}{ Innovative literacy } & groups & 69.435 & 4 & \multirow{3}{*}{$3.932 * *$} & \multirow{3}{*}{$5>1 ; 5>2 ; 5>3 ; 4>1 ; 4>2$} \\
\hline & Within-group & 4225.267 & 957 & & \\
\hline & Total & 4294.703 & 961 & & \\
\hline \multirow{3}{*}{ Self-discipline and critical literacy } & Groups & 25.755 & 4 & \multirow{3}{*}{$2.903^{*}$} & \multirow{3}{*}{$5>1 ; 5>3 ; 4>1 ; 3>1 ; 2>1$; } \\
\hline & Within-group & 2122.823 & 957 & & \\
\hline & total & 2148.578 & 961 & & \\
\hline
\end{tabular}

Note : * indicates $\mathrm{p}<0.05$, ** indicates $\mathrm{p}<0.01$, *** indicates $\mathrm{p}<0.001$; family income column: "1" stands for " 1000 yuan or less (month)", "2" stands for " 1001 3000 yuan", " 3 " stands for "3001-5000 yuan", "4" stands for "5001-10000 yuan", and "5" stands for "10001 yuan or more".

As we can see from table 5, in general, the higher the monthly household income level, the higher the overall score of college students' Internet literacy, emerging technology literacy, innovative literacy, and self-discipline and critical literacy. This may be because that high family income can provide students with better physical conditions for their growth, using online learning information technology to surf the Internet.

(4) The Internet literacy level of college students whose families often carry out Internet literacy education is higher than that of college students whose families rarely carry out education.

Table 6: The condition of college students' Internet literacy of different family education

\begin{tabular}{|c|c|c|c|c|c|c|c|}
\hline & & \multicolumn{4}{|c|}{ Family Internet literacy education } & \multirow{2}{*}{$\mathrm{F}$} & \multirow{2}{*}{$\mathrm{P}$} \\
\hline & & never & rare & often & frequent & & \\
\hline \multirow{3}{*}{$\begin{array}{l}\text { Internet literacy total } \\
\text { score }\end{array}$} & $\mathrm{N}$ & 201 & 544 & 206 & 11 & \multirow{3}{*}{$5.550 * *$} & \multirow{3}{*}{0.001} \\
\hline & $\mathrm{M}$ & 71.08 & 72.67 & 74.30 & 74.18 & & \\
\hline & SD & 8.15 & 7.71 & 8.57 & 11.69 & & \\
\hline \multirow{2}{*}{$\begin{array}{l}\text { Security and moral } \\
\text { literacy }\end{array}$} & $\mathrm{M}$ & 18.88 & 19.24 & 19.57 & 19.00 & \multirow{2}{*}{1.999} & \multirow{2}{*}{0.113} \\
\hline & SD & 2.94 & 2.85 & 2.85 & 3.26 & & \\
\hline \multirow{2}{*}{$\begin{array}{l}\text { Emerging technology } \\
\text { literacy }\end{array}$} & $\mathrm{M}$ & 14.45 & 15.08 & 15.52 & 15.64 & \multirow{2}{*}{$7.206^{* * * *}$} & \multirow{2}{*}{0.000} \\
\hline & SD & 2.67 & 2.18 & 2.50 & 2.94 & & \\
\hline \multirow{2}{*}{ Innovative literacy } & $\mathrm{M}$ & 10.55 & 10.80 & 11.20 & 11.45 & \multirow{2}{*}{$3.684^{*}$} & \multirow{2}{*}{0.012} \\
\hline & SD & 2.31 & 1.96 & 2.25 & 2.34 & & \\
\hline \multirow{2}{*}{ Publishing literacy } & $\mathrm{M}$ & 9.85 & 9.81 & 9.86 & 10.00 & \multirow{2}{*}{0.124} & \multirow{2}{*}{0.946} \\
\hline & SD & 1.45 & 1.59 & 1.69 & 1.73 & & \\
\hline \multirow{2}{*}{$\begin{array}{l}\text { Self-discipline and } \\
\text { critical literacy }\end{array}$} & $\mathrm{M}$ & 8.49 & 8.67 & 8.99 & 8.73 & \multirow{2}{*}{$3.925 * *$} & \multirow{2}{*}{0.008} \\
\hline & SD & 1.49 & 1.48 & 1.47 & 1.95 & & \\
\hline
\end{tabular}

Note: * indicates $\mathrm{p}<0.05, * *$ indicates $\mathrm{p}<0.01, * * *$ indicates $\mathrm{p}<0.001$

It can be seen from Table 6 that there are 745 people who never and rare have Internet literacy education in their family, which accounts for $77.4 \%$ of the total, that is, two-thirds of the total families. Internet literacy education still has a long way to go.

In addition, in terms of Internet literacy total score $(\mathrm{F}=5.550, \mathrm{p}<0.01)$ and emerging technology literacy $(\mathrm{F}=7.206, \mathrm{p}<0.001)$, innovative literacy $(\mathrm{F}=3.684$, $\mathrm{p}<0.05)$ and self-discipline and critical literacy $(\mathrm{F}=3.925, \mathrm{p}<0.01)$, there are significant differences existing between college students with different household Internet literacy education condition.

Table 7: ANOVA of college students' Internet literacy of different family education

\begin{tabular}{|c|c|c|c|c|c|}
\hline & & $\mathrm{SS}$ & df & $\mathrm{F}$ & LSD \\
\hline \multirow{3}{*}{$\begin{array}{l}\text { Internet literacy total } \\
\text { score }\end{array}$} & Groups & 1077.251 & 3 & \multirow{3}{*}{$5.550 * *$} & \multirow{3}{*}{ often>never ; often $>$ rare ; rare>never } \\
\hline & $\begin{array}{l}\text { Within- } \\
\text { group }\end{array}$ & 61981.316 & 958 & & \\
\hline & Total & 63058.567 & 961 & & \\
\hline \multirow{3}{*}{$\begin{array}{l}\text { Emerging technology } \\
\text { literacy }\end{array}$} & Groups & 121.216 & 3 & \multirow{3}{*}{$7.206 * * *$} & \multirow{3}{*}{ ofte>never ; often>rare ; rare>never } \\
\hline & $\begin{array}{l}\text { Within- } \\
\text { group }\end{array}$ & 5371.679 & 958 & & \\
\hline & Total & 5492.895 & 961 & & \\
\hline \multirow[b]{2}{*}{ Innovative literacy } & Groups & 48.984 & 3 & \multirow[b]{2}{*}{$3.684 *$} & \multirow[b]{2}{*}{ often>never ; often>rare } \\
\hline & $\begin{array}{l}\text { Within- } \\
\text { group }\end{array}$ & 4245.719 & 958 & & \\
\hline
\end{tabular}


Citation: Wenying Wu, et al., 2019. Internet Literacy among College Students: an Empirical Research on Characteristics of College Students' Internet literacy. Journal of Applied Sciences Research., 15(3): 7-12. DOI: 10.22587/jasr.2019.15.5.2

\begin{tabular}{|c|c|c|c|c|c|}
\hline & total & 4294.703 & 961 & & \\
\hline \multirow{2}{*}{$\begin{array}{c}\text { Self-discipline and } \\
\text { critical literacy }\end{array}$} & Groups & 26.091 & 3 & \multirow{2}{*}{$3.925^{* *}$} & often>never ; often>rare \\
\cline { 2 - 4 } & $\begin{array}{c}\text { Within- } \\
\text { group }\end{array}$ & 2122.487 & 958 & \\
\cline { 2 - 4 } & total & 2148.578 & 961 & \\
\hline
\end{tabular}

Note: * indicates $\mathrm{p}<0.05, * *$ indicates $\mathrm{p}<0.01, * * *$ indicates $\mathrm{p}<0.001$

From Table 7, it can be found that college students who often conduct Internet literacy education in their homes have significantly higher Internet literacy level, emerging technology literacy, innovative literacy and self-discipline and critical literacy than those who never conduct Internet literacy education in their family.

(5) The Internet literacy level of college students who are positive on the Internet evaluation is higher than that of the college students who are being negative on the Internet.

Table 8: The condition of college students' Internet literacy of different network evaluation

\begin{tabular}{|c|c|c|c|c|c|c|c|c|}
\hline & & \multicolumn{5}{|c|}{ Internet evaluation } & \multirow{2}{*}{$\mathrm{F}$} & \multirow{2}{*}{$\mathrm{P}$} \\
\hline & & Very nagative & negative & neutral & positive & Very positive & & \\
\hline \multirow{3}{*}{$\begin{array}{c}\text { Internet } \\
\text { literacy total } \\
\text { score }\end{array}$} & $\mathrm{N}$ & 4 & 56 & 341 & 499 & 62 & \multirow{3}{*}{$23.206^{* * *}$} & \multirow{3}{*}{.000} \\
\hline & $\mathrm{M}$ & 63.50 & 59.75 & 61.73 & 64.77 & 68.69 & & \\
\hline & SD & 10.66 & 6.17 & 6.76 & 6.67 & 8.38 & & \\
\hline \multirow[t]{2}{*}{$\begin{array}{l}\text { Security and } \\
\text { moral literacy }\end{array}$} & M & 17.75 & 17.73 & 18.72 & 19.64 & 20.32 & \multirow[t]{2}{*}{$12.006 * * *$} & \multirow[t]{2}{*}{.000} \\
\hline & SD & 3.95 & 2.48 & 3.08 & 2.61 & 3.05 & & \\
\hline \multirow[t]{2}{*}{$\begin{array}{c}\text { Emerging } \\
\text { technology } \\
\text { literacy }\end{array}$} & M & 15.00 & 14.32 & 14.43 & 15.35 & 16.66 & \multirow[t]{2}{*}{$17.256^{* * * *}$} & \multirow[t]{2}{*}{.000} \\
\hline & SD & 4.40 & 2.22 & 2.35 & 2.23 & 2.70 & & \\
\hline \multirow{2}{*}{$\begin{array}{c}\text { Innovative } \\
\text { literacy }\end{array}$} & $\mathrm{M}$ & 11.50 & 10.55 & 10.39 & 11.02 & 12.05 & \multirow{2}{*}{$10.669 * * *$} & \multirow{2}{*}{.000} \\
\hline & SD & 2.38 & 1.76 & 1.96 & 2.10 & 2.63 & & \\
\hline \multirow{2}{*}{$\begin{array}{c}\text { Publishing } \\
\text { literacy }\end{array}$} & $\mathrm{M}$ & 9.50 & 9.23 & 9.74 & 9.93 & 10.06 & \multirow{2}{*}{$3.150 *$} & \multirow{2}{*}{.014} \\
\hline & SD & 1.29 & 1.57 & 1.60 & 1.54 & 1.76 & & \\
\hline \multirow{2}{*}{$\begin{array}{l}\text { Self-discipline } \\
\text { and critical } \\
\text { literacy }\end{array}$} & $\mathrm{M}$ & 9.75 & 7.91 & 8.46 & 8.83 & 9.60 & \multirow[b]{2}{*}{$13.886^{* * * *}$} & \multirow[b]{2}{*}{.000} \\
\hline & SD & 0.96 & 1.43 & 1.38 & 1.47 & 1.75 & & \\
\hline
\end{tabular}

Note: * indicates $\mathrm{p}<0.05, * *$ indicates $\mathrm{p}<0.01, * * *$ indicates $\mathrm{p}<0.001$

It can be seen from Table 8 that most of the college students are positive on the Internet, reaching 561 people, accounting for $58.3 \%$ of the total, while there are only 60 people being negative on the Internet, accounting for $6.2 \%$ of the total. It is believed that most college students think the network influence is positive or neutral to themselves, accounting for the vast majority of the test group.

In addition, we can also see from this table that in all these five dimensions, different opinions about the Internet will lead to different Internet Literacy level.

Table 9: ANOVA of college students' Internet literacy of different network evaluation

\begin{tabular}{|c|c|c|c|c|c|}
\hline & & SS & df & $\mathrm{F}$ & LSD \\
\hline \multirow{3}{*}{$\begin{array}{l}\text { Internet literacy total } \\
\text { score }\end{array}$} & Groups & 4309.596 & 4 & \multirow{3}{*}{$23.206^{* * *}$} & \multirow{3}{*}{$\begin{array}{l}5>4 ; 5>3 ; 5>2 ; \\
4>3 ; 4>2 ; 3>2 ;\end{array}$} \\
\hline & $\begin{array}{l}\text { Within- } \\
\text { group }\end{array}$ & 44431.349 & 957 & & \\
\hline & total & 48740.945 & 961 & & \\
\hline \multirow{3}{*}{$\begin{array}{l}\text { Security and moral } \\
\text { literacy }\end{array}$} & Groups & 379.562 & 4 & \multirow{3}{*}{$12.006^{* * *} *$} & \multirow{3}{*}{$\begin{array}{c}5>3 ; 5>2 ; 4>3 ; \\
4>2 ; 3>2 ;\end{array}$} \\
\hline & $\begin{array}{l}\text { Within- } \\
\text { group }\end{array}$ & 7563.873 & 957 & & \\
\hline & Total & 7943.436 & 961 & & \\
\hline \multirow{3}{*}{$\begin{array}{c}\text { Emerging technology } \\
\text { literacy }\end{array}$} & Groups & 369.527 & 4 & \multirow{3}{*}{$17.256^{* * *} *$} & \multirow{3}{*}{$\begin{array}{c}5>4 ; 5>3 ; 5>2 ; \\
4>3 ; 4>2 ;\end{array}$} \\
\hline & $\begin{array}{l}\text { Within- } \\
\text { group }\end{array}$ & 5123.368 & 957 & & \\
\hline & Total & 5492.895 & 961 & & \\
\hline \multirow{3}{*}{ Innovative literacy } & Groups & 183.348 & 4 & \multirow{3}{*}{$10.669 * * *$} & \multirow{3}{*}{$\begin{array}{c}5>4 ; 5>3 ; 5>2 ; \\
4>3 ;\end{array}$} \\
\hline & $\begin{array}{l}\text { Within- } \\
\text { group }\end{array}$ & 4111.355 & 957 & & \\
\hline & Total & 4294.703 & 961 & & \\
\hline \multirow{3}{*}{ Publishing literacy } & Groups & 31.309 & 4 & \multirow{3}{*}{$3.150 *$} & \multirow{3}{*}{$5>2 ; 4>2 ; 3>2 ;$} \\
\hline & $\begin{array}{l}\text { Within- } \\
\text { group }\end{array}$ & 2378.073 & 957 & & \\
\hline & Total & 2409.381 & 961 & & \\
\hline \multirow{3}{*}{$\begin{array}{l}\text { Self-discipline and } \\
\text { critical literacy }\end{array}$} & groups & 117.862 & 4 & \multirow{3}{*}{$13.886^{* * * *}$} & \multirow{3}{*}{$\begin{array}{c}5>4 ; 5>3 ; 5>2 ; \\
4>3 ; 4>2 ; \\
3>2 ; 2>1 ;\end{array}$} \\
\hline & $\begin{array}{l}\text { Within- } \\
\text { group }\end{array}$ & 2030.716 & 957 & & \\
\hline & Total & 2148.578 & 961 & & \\
\hline
\end{tabular}

Note: * indicates $\mathrm{p}<0.05$, ** indicates $\mathrm{p}<0.01$, *** indicates $\mathrm{p}<0.001$; network impact evaluation column: " 1 " stands for very negative, " 2 " stands for negative, " 3 " stands for neutral, " 4 " is more positive, " 5 " is very positive

From Table 9, it can be found that the college students who are positive on Internet have a significantly higher level of Internet literacy total score, security and moral literacy, emerging technology literacy, innovative literacy, publishing literacy and self-discipline and critical literacy.

5. Conclusions 
The research shows that the overall situation of college students' Internet literacy is in good condition. The highest level of Internet literacy that college students have is research literacy, followed by safety ethics and information technology literacy. The last two are self-discipline critical literacy and interactive innovation literacy.

The concrete characteristics are as follows:

1) The network literacy of college students who major in science and engineering is higher than that of college students who major in liberal arts.

2) Differences in college students' family income will lead to a different level of Internet literacy, and students who have higher family income have higher level of Internet literacy.

3) The Internet literacy of college students who often conduct online literacy education is higher than that of college students who rarely have this kind of education.

4) The Internet literacy level of college students who have a positive view on the network evaluation is higher than that of the university students who have a negative view on the network evaluation.

\section{Acknowledgement}

The authors gratefully acknowledge financial support from the project of The National Social Science Found of China (Grant No. 15BXW069). We would like to thank all colleagues for their long-lasting support and caring in Dalian University of Technology, Liaoning, China.

\section{References}

[1] The $37^{\text {th }}$ Report on Internet development in China. (2016). CNNIC http://www.cnnic.net.cn/hlwfzyj/hlwxzbg/. [Retrieved on April 30, 2016]

[2] Leung, L., \&Lee, P. S. N. (2012). Impact of Internet Literacy, Internet Addiction, and Internet Activities on Academic Performance. Social Science Computer Review, 30, 403-418.

[3] Leung, L. (2010). Effects of Internet Connectedness and Information Literacy on Quality of Life. Social Indicators Research, 98, $273-290$.

[4] Ding, C., \& Liu, B. (2010). Media literacy among college students. Beijing: Beijing Normal University. [in Chinese]

[5] Jiang, H. (2007). Media literacy of university students: current situation and coping strategies. Chinese Journal of Adult Education, 10: 52-53. [in Chinese]

[6] Livingstone S. Engaging with media - A matter of literacy? [J]. Communication, Culture \& Critique, 2008.1(1): 51-62.

[7] Association of Colleges and Research $\quad$ Libraries. Introduction to Information Literacy[OL].[2010,6,24]http://www.ala.org/ala/mgrps/divs/acrl/issues/infolit/overview/intro/index.cfm.

[8] Louis Leung, Paul S. N. Lee. Impact of Internet Literacy, Internet Addiction and Internet Activitieson Academic Performance[J]. Social Science Computer Review,2012(30):403-418.

[9] Tayie, Pathak - Shelat, Hirsjarvi. Young People's Interaction with Media in Egypt,India, Finland,Argentina and Kenya [J].Comunicar,2012(39):53-62..

[10] Falter, M.M. You are wearing kurt's necklace! the rhetorical power of glee in the literacy classroom[J]. Journal of Adolescent \& Adult literacy, 2013,57(4):289-297.

[11] Parry,B. Popular culture, participation and progression in the literacy classroom [J]. Literacy,2014,48(1):14-22.

[12] Burnett C,Merchant G. Is there a space for critical literacy in the context of social media? [J].English Teaching - practice and Critique, 2011, $10(1): 41-57$.

[13] Gozalvez. Education for Democratic Citizenship in a Digital Culture[J].Comunicar,2011(36):131-138.

[14] Nikken, Janze. Developing scales to measure parental mediation of young children's internet use[J]. Learning Media and Technology, 2014,39(2):250-266.

[15] Pu Wei: On the Significance, Contents and Methods of Media Education[J].Modern Communication.1997(1):29-33.[in Chinese]

[16] Louis Leung. Effects of Internet Connectedness and Information Literacy on Quality of Life [J].Social Indicators Research,2010,98(2):273-290.

[17] Beniler P. M., Chou C.P. Practical Issues in Structrural Modeling[J]. Sociological Methods and Research.1987,16(8):78-117. 